\title{
Swat Based Soil Erosion Modeling of Nashe, Blue Nile Basin, Ethiopia
}

\author{
Dereje Gizaw Namomsa ${ }^{1,}$, , Tamene Adugna ${ }^{2}$ \\ ${ }^{1}$ Department Hydraulic and Water Resource Engineering, Wollega University, Oromia, Ethiopia \\ ${ }^{2}$ School of Civil and Environmental Engineering, Jimma Institute of Technology, JIT, Jimma University, Oromia, Ethiopia
}

Email address:

Gizawd395@gmail.com (D. G. Namomsa)

${ }^{*}$ Corresponding author

\section{To cite this article:}

Dereje Gizaw Namomsa, Tamene Adugna. Swat Based Soil Erosion Modeling of Nashe, Blue Nile Basin, Ethiopia. Journal of Civil, Construction and Environmental Engineering. Vol. 4, No. 1, 2019, pp. 35-41. doi: 10.11648/j.jccee.20190401.14

Received: January 29, 2019; Accepted: March 11, 2019; Published: May 27, 2019

\begin{abstract}
In worldwide, soil erosion effect on the water storage structures is significant for proper management of water resource and its use. The effect of soil erosion, improper management system and lack of suitable soil conservation measures have played important role for food production, and global warming problem. For modeling of soil erosion in Nashe watershed a geographical information system (GIS) version-based SWAT has been used to evaluate sensitivities and prone soil erosion area. To predict spatial \& temporal soil erosion distribution stream flow calibration and validation of the soil and water assessment tool were applied using the compatible version of SWATCUP against stream flow for Nashe watershed were taken to estimate model performance on monthly basis. Soil erosion involves all parameters are important for feasible conservation of natural, agricultural and built-up environments. To model the soil erosion the analysis was done on over land runoff, soil loss and sediment yield. The model performance(SWAT) has been evaluated by using statistical parameters of $\left(\mathrm{R}^{2}\right)$ and $\left(\mathrm{E}_{\mathrm{NS}}\right)$ $0.79 \& 0.75$ respectively for calibration and validation results 0.71 and 0.65 for $R^{2}$ and $E_{N S}$ respectively, the results indicate that the best model to forecast hydrological process of the basin or catchment.
\end{abstract}

Keywords: Modeling, Nashe, Sediment Yields, Soil Erosion, SWAT

\section{Introduction}

Soil erosion is worldwide environmental crisis that threaten agricultural areas at an alarming rate. The improper management system and lack of suitable soil conservation measures have been the main causes of soil erosion and land degradation problems in the country. Soil erosion and Land degradation are resulted from increasing cultivation of mountainous and steeper slopes, without protective measures against it. The land is strictly harmed by process of soil erosion and its associated effects. The process includes the detachment, transport and deposition of soil particles by the erosive force of rain drops and surface flow of water. Erosion of the land surface takes place in the form of sheet erosion, rill and inter-rill erosion, and gully erosion [2]. The main objective of this study is to estimate spatial and temporal patterns of soil erosion and calibrate $\&$ validate the hydrological model using Geographic Information System based version of the Soil and Water Assessment Tool model. Ethiopia loses about 1.3 billion metric tons of fertile soil every year and the land degradation through soil erosion is increasing a thigh rate [7]. To save soil and water resource degradation, immediate measure should be taken.

In 2006, construction of hydropower and irrigation dam Nashe watershed, western Ethiopia, which caused serious land use changes in the watershed. Before the dam was constructed, the communities living in the area were not considered, and therefore have resulted in forests being converted to cultivated land. These changes in land use have made widespread soil erosion. Due to this, an increased in crop land on steep slope has occurred and which potentially has increased erosion problems in the area. The converted to agricultural and without using control measures and appropriate land management practice which potentially has increased soil erosion in the area. 


\section{Study Area Description}

The study area is located in Horro Guduru Wollega Zone, West Wollega, Oromia reginal state, western basin between $9^{0} 50^{\prime} 00^{\prime \prime}-9^{0} 25^{\prime} 00^{\prime \prime}$ latitude and $37^{0} 0^{\prime} 00^{\prime \prime}-37^{0} 15^{\prime} 00^{\prime \prime}$ longitude is the part of Blue Nile river basin which contains three watershed (Fincha'a, Amerti and Nashe) watersheds
(Figure1). Nashe river sub basin, which is the study area, is located in the north western part of the Blue Nile basin and upper of Fincha'a valley. The basin is characterized by mean maximum and minimum temperatures of $11^{\circ} \mathrm{C}$ and $18^{\circ} \mathrm{C}$ respectively. Average annual rainfall in the area is about $1566.5 \mathrm{~mm}$, which falls during 3-month main rainy season from mid-June to mid-September.

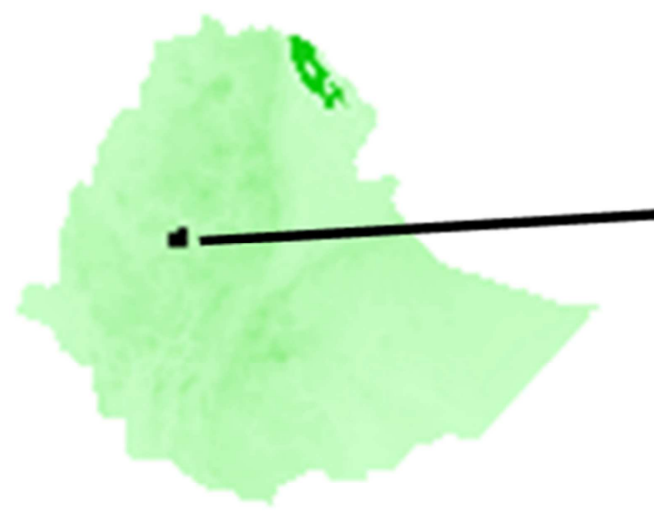

Ethiopia

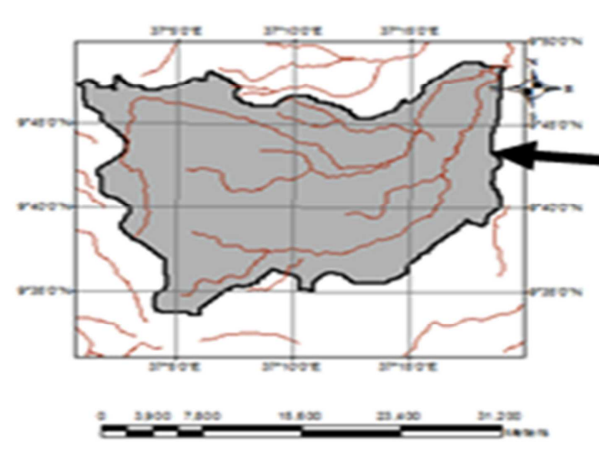

Nashe basin

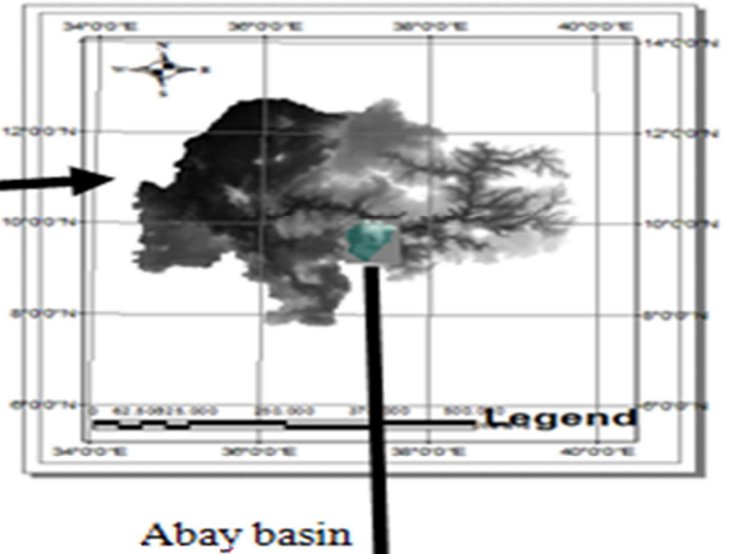

Abay basin

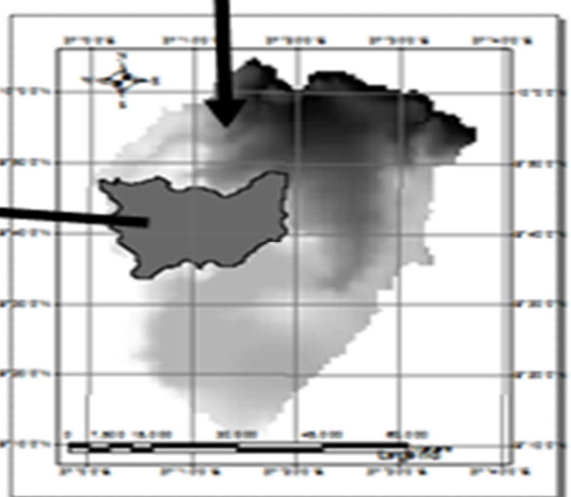

Fincha'a basin

Figure 1. The location of study area.

\section{Materials and Methods}

Materials and tools used for input data preparation and analysis

ArcGIS9.3, ArcSWAT2009, PCPSTAT, dew02, SWATCUP, XLSTAT2005, DEM, Meteorological data, Hydrological data and Soil map data.

The procedure of this work will be the following component.

Data collecting, Data processing, Input data, Running model, Sensitivity Analysis test, Calibration \& Validation and Analysis result of Model.

\subsection{SWAT Model Description}

The Soil and water assessment tool (SWAT) are the physical based hydrological model developed by USDA Agricultural Research Service (ARS) [1]. SWAT incorporates features of several ARS models. It is long term and computationally efficient watershed model. To model hydrology, sediment, nutrient transport the watershed is divided in to sub basins. SWAT divides area of sub basin in to morel and units, possessing similar land use, soil type and applied management strategies for better estimation of the loadings (flows and sediment) from sub basin and predicts the influence of land management practice on constituent yields from a watershed.

SWAT, has been recently been adapted to more effectively model hydrological process in monsoonal climates such as Ethiopia [14]. Simulation of very large and complex basins or a variety of management strategies can be performed without excessive investment of time or money, and enables users to study long term impact. Inaddition, SWAT uses MUSLE to simulate sediment erosion from HRU which replace the traditional USLE equation. MUSLE uses run off factor than rain fall factor to estimate sediment yield [17]. 
Therefore, SWAT model was selected for this study.

\subsubsection{Hydrology Component}

To investigate the soil erosion modeling of Nashe watershed. The Soil and Water Assessment Tool (SWAT) model was used. SWAT was developed for the purpose of simulation and to predict impact of land management practice on water and sediment. In SWAT, the water balance is computed from the soil water content which is described by the following equation.

$$
\mathrm{SW}_{\mathrm{t}}=\mathrm{SW}_{\mathrm{o}}+\sum_{i=1}^{t}(R d a y-Q \operatorname{surf}-E a-W \text { seep }-Q g w)
$$

Where $\mathrm{SW}_{\mathrm{t}}$ : the final soil water content $(\mathrm{mm})$, SWo: the initial water content $(\mathrm{mm})$, $\mathrm{t}$ : the time (days), $\mathrm{R}_{\text {day }}$ : the amount of precipitation on day $\mathrm{i}(\mathrm{mm}), \mathrm{Q}_{\text {surf }}$ : the amount of surface runoff on day $\mathrm{i}(\mathrm{mm}), \mathrm{E}_{\mathrm{a}}$ : the amount of evapotranspiration on day $\mathrm{i}(\mathrm{mm})$, Wseep: the amount of water entering the vadose zone from the soil profile on day $i$ $(\mathrm{mm}), \mathrm{Q}_{\mathrm{gw}}$ the amount of the return flow on day $\mathrm{i}(\mathrm{mm})$.

\subsubsection{Surface Runoff Component}

To set up the model the amount of rain fall is one of the input parameters among to the weather parameter which is required. The SCS curve number is used to determine runoff depth [13].

$$
\begin{gathered}
\text { Qurf }=\frac{(\text { Rday }-I a) 2}{(\text { Rday-Ia+S })} \\
\mathrm{Ia}=0.2 \mathrm{~S} \\
\mathrm{~S}=25.4\left(\frac{1000}{C N}-10\right) \\
\text { Qsurf }=\frac{(\text { Rday }-0.2 S) 2}{(\text { Rday }+0.8 S)}
\end{gathered}
$$

Where, $\mathrm{Qs}_{\mathrm{urf}}$ is the accumulated runoff for rain fall excess $\left(\mathrm{mmH}_{2} \mathrm{O}\right), \mathrm{R}_{\text {day }}$ is the rain fall depth for the day $\left(\mathrm{mmH}_{2} \mathrm{O}\right), \mathrm{I}_{\mathrm{a}}$ is the initial abstraction which includes surface storage, interception and infiltration prior to runoff $\left(\mathrm{mmH}_{2} \mathrm{O}\right)$ and commonly approximated as $0.2 \mathrm{~S}, \mathrm{CN}$ is the curve number for the day, Runoff only occur when $\mathrm{R}_{\text {day }}>$ Ia. The peak runoff rate is the maximum runoff flow rate that occurs with a given rainfall event. The peak runoff rate is an indicator of the erosive power of the storm and is used to predict sediment loss. SWAT calculates the peak runoff rate with modified rational method [17]. The corresponding equationis:

$$
\text { q peak }=\frac{C x i x A}{3.6}
$$

where; $q$ peak $=$ runoff $\operatorname{rate}(\mathrm{m} / \mathrm{s}), \mathrm{i}=$ rainfall intensity $(\mathrm{mm} / \mathrm{h})$, $\mathrm{A}=$ sub basin area $(\mathrm{km}), \mathrm{C}=$ runoff coefficient

\subsubsection{Sediment Yield Component}

SWAT model calculates the surface erosion and sediment yield within each HRU with the modified Universal Soil Loss Equation (MUSLE) [17]. The sediment supply from the individual HRU is computed by the modified universal soil loss equation.

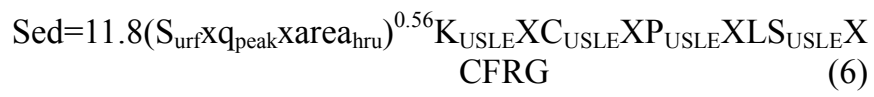

Where; Sed=sediment yield ( $\mathrm{t} /$ day), $\mathrm{Q}=$ surface runoff volume $(\mathrm{mm}), \mathrm{q}=$ peak run off rate $(\mathrm{m} / \mathrm{s})$, area=area of HRU (ha), $\mathrm{KUSLE}=$ erodiblity factor, $\mathrm{CUSLE}=$ cover and management factor, PUSLE $=$ support practice factor, LSUSLE=topographic factor, $\mathrm{CFRG}=$ coarse fragment factor.

\subsection{Data Collection and Source}

The required necessary meteorically input data for this study were daily rain fall data, max and Min Temperature, Wind speed, Radiation and relative humidity collected from

\begin{tabular}{|c|c|c|}
\hline Date type & Source & Description \\
\hline DEM & Ministry of Water, Irrigation and Energy (MoWIE) & Digital Elevation Model \\
\hline Land cover & Ministry of Water, Irrigation and Energy (MoWIE) & Land use classification map \\
\hline Soil & Ministry of Water, Irrigation and Energy (MoWIE) & Soil classification map \\
\hline Weather & $\begin{array}{l}\text { National Meteorological Service A gency (NMSA) and Weather generator } \\
\text { (Intermet) }\end{array}$ & $\begin{array}{l}\text { 1. Daily rain fall data } \\
\text { 2. Daily max. and Min. Temperature } \\
\text { 3. Daily Wind speed } \\
\text { 4. Daily Radiation } \\
\text { 5. Daily relative humidity }\end{array}$ \\
\hline
\end{tabular}
Ethiopian National Meteorological Service Agency from different station. And the required spatially data Digital Elevation Model (DEM), land use/land cover map, soil map, and soil data were collected from different sources (table 1).

Table 1. Input data and their sources.

The daily stream flow data for study area obtained from Ethiopian Ministry of water, Irrigation and Energy hydrology department. Nashe River flow daily data which is used to calibrate and validate the SWAT model were collected from ministry of water, energy and irrigation bureau.

\subsection{Data Analysis and Processing}

After all data were collected it was made analysis of collected data. Because of input data collected lacks the quality and quantity data. Hydrological data missing data computation method was used. For detecting inconsistency, to correct and adjust collected data was checked by double mass curve method its consistency.

\subsection{Simulation $S W A T$}

Finally, the SWAT model has been run and read the SWAT 
model output by importing files to data base and saving to place of interest or by opening the output. std. For this study, the SWAT simulation performed Output times step (Monthly) and rainfall distribution (skew normal) for the watershed. SWAT- CUP is used for sensitivity analysis, calibration and validation.

\subsection{Model Performance Assessment}

To evaluate the accuracy of overall model calibration and validation, different statistical indicators are used for SWAT model. Coefficient of determination $\left(\mathrm{R}^{2}\right)$ : Is the indicator of relationship between the measured and simulated values. $\mathrm{R}^{2}$ ranges from 0 to 1 ; with higher value the more approach to 1 indicating better agreement and value less than 0.5 indicates a poor performance of the model.

$$
\mathrm{R}^{2}=\left[\frac{\sum_{i-1}^{n}\left(O i-O^{\prime}\right)\left(S i-S^{\prime}\right)}{\sqrt{\sum_{i-1}^{n}\left(O i-O^{\prime}\right) 2} \sqrt{\sum_{i-1}^{n}\left(S i-S^{\prime}\right) 2}}\right]
$$

Where $\mathrm{Oi}=$ Observed stream flow, $\mathrm{Si}=$ Simulated stream flow, $S^{\prime}=$ Mean Simulated stream flow

$\mathrm{O}^{\prime}=$ Mean Observed stream flow, $\mathrm{n}=$ Number of observations.

Nash- Sutcliffe Efficiency $\left(\mathrm{N}_{\mathrm{SE}}\right)$ : NSE measures the degree of fitness of the observed and simulated data variance. The more the NSE approaches to 1, indicates the better will be the model performance.

$$
N S E=1-\frac{\sum_{i=1}^{n}(S i-O i) 2}{\sum_{i=1}^{n}\left(O i-O^{\prime}\right) 2}
$$

\section{Result and Discussion}

\subsection{Sensitivity Analysis}

A sensitivity analysis was conducted to determine which of the unknown variables and most sensitive parameters have the largest effect on the stream flow in the model result. The result from sensitivity analysis was provided by ranking of input parameters that have most impact on stream flow output. Out of these parameters only ten (10) of them, which have greatest influence (table2) on model output, were selected as parameters for calibration process.

Table 2. Result from the sensitive analysis are shown below table.

\begin{tabular}{llllll}
\hline Parameters & Rank & P-value & t-value & Fitted value & Min value \\
\hline CN2 & 1 & 0.000 & -15.187 & 0.000 & -0.200 \\
ESCO & 2 & 0.413 & -0.826 & 0.900 & 0.800 \\
SOL_AWC & 3 & 0.345 & -0.954 & 0.100 & -0.200 \\
SOL_BD & 4 & 0.787 & 0.271 & 0.050 & -0.500 \\
GW_REVAP & 5 & 0.490 & -0.695 & 0.100 & 0.000 \\
CH_K2 & 6 & 0.282 & 1.089 & 67.500 & 5.000 \\
CH_N2 & 7 & 0.490 & 1.041 & 0.150 & 0.000 \\
SFTMP & 8 & 0.994 & -0.006 & 0.000 & -500 \\
GWQMN & 9 & 0.280 & 1.094 & 1.000 & 0.200 \\
GW_DELAY & 10 & 0.000 & -14.702 & 240.000 & 0.000 \\
\hline
\end{tabular}

\subsection{Model Calibration}

The statically result for the calibration model performance is played satisfactory (coefficient of determination $\mathrm{R}^{2}$ and the Nash Sutcliffe equation $\mathrm{N}_{\mathrm{SE}}$ ) between simulated and observed flow was 0.79 and 0.75 respectively. Efficiency values $\geq 0.50$ for evaluating the modeled results are with in the acceptable level with them assured stream low at Nashe River gauging station. $\mathrm{N}_{\mathrm{SE}}$ and $\geq 0.60$ for $\mathrm{R}^{2}$ are considered adequate for SWAT model application in management planning as it captures the variability of simulated and observed values well [9]. This indicates that results were estimated by the visual comparison of graphs also other measures of the model performance during calibration for stream flow (figure2) which is important to identify model partiality and variation in the timing and amount of peak flows simulated. It shows the relationship between the model simulation output and observed data for model calibration.

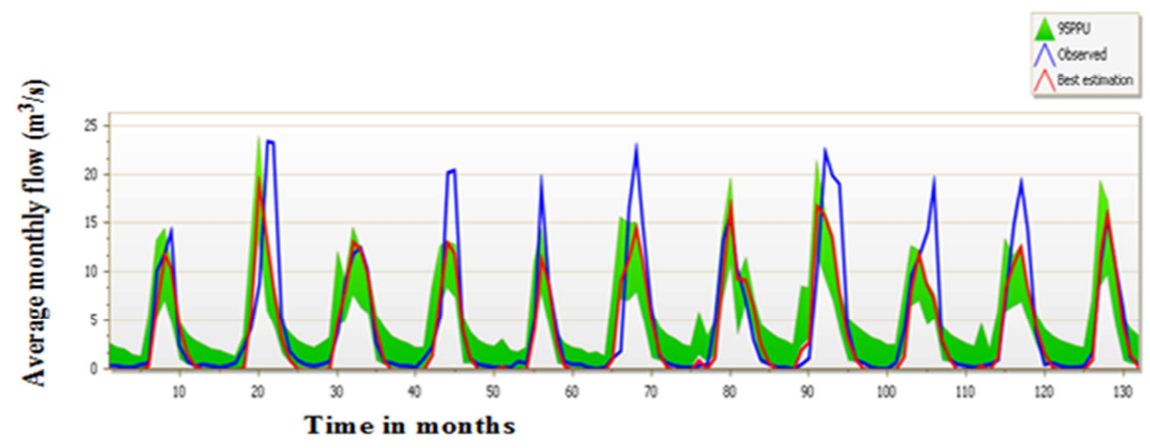

Figure 2. Calibration results of monthly observed and simulated flows by SUFI-2 of Nashe watershed. 


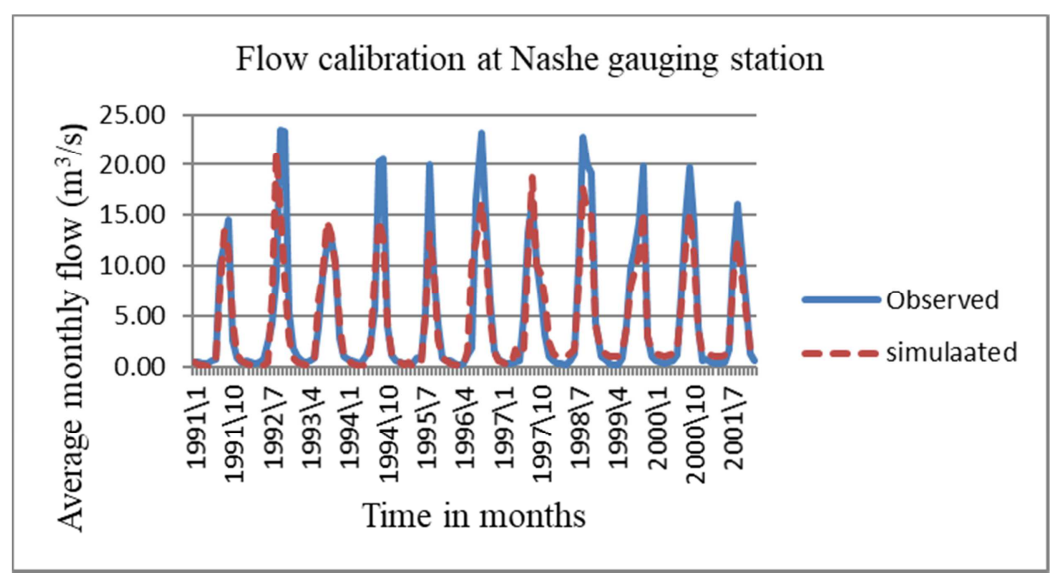

Figure 3. Calibration results of monthly observed and simulated flows by SUFI-2 of Nashe watershed.

\subsection{Model Validation}

For this study, monthly validation of statistical analysis showed that good agreement between observed and simulated stream flow, which was explained by $\mathrm{R}^{2}$ and $\mathrm{N}_{\mathrm{SE}}$ values ( 0.71 for $\mathrm{R}^{2}$ and 0.65 for $\mathrm{N}_{\mathrm{SE}}$. The validation result represents that $\mathrm{SWAT}$ model accurately predict stream flow, by showing the relationship between the simulated output and observed data (figure 4).

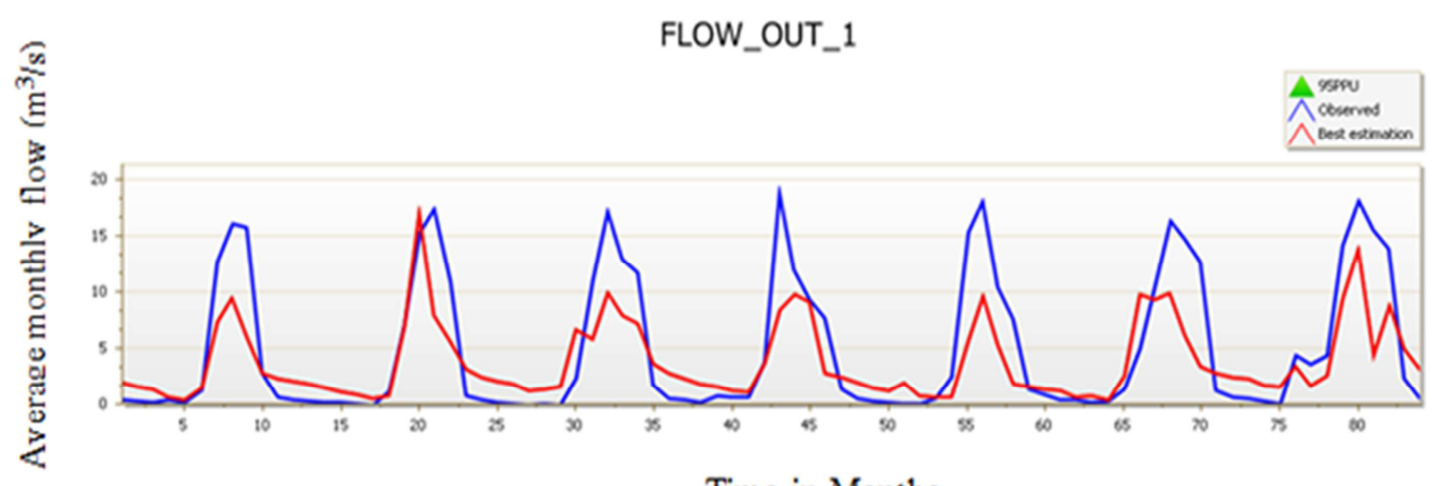

Time in Months

Figure 4. Validation results of monthly observed and simulated flows by SUFI-2 of Nashe watershed.

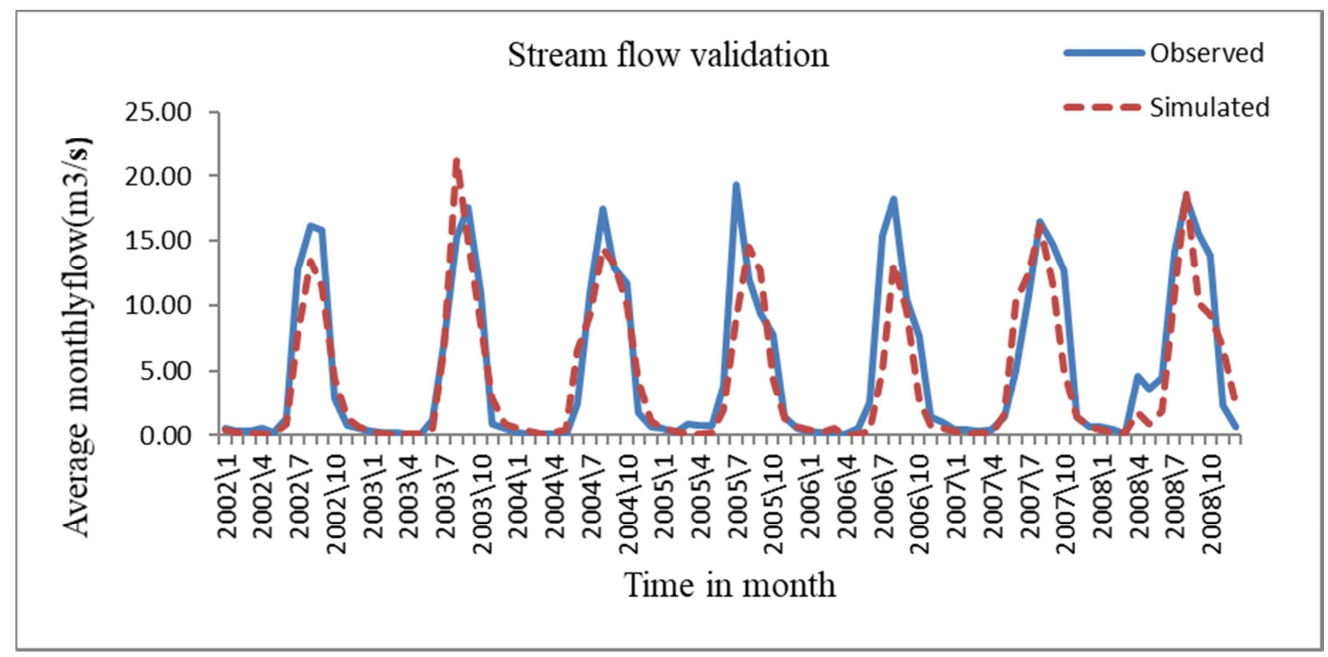

Figure 5. Validation results of monthly measured and simulated flow.

\subsection{Soil Erosion Prone Area}

To encourage management planning and discouraging mismanagement of catchment identifying spatially soil erosion prone area is a vital one (table3). SWAT model divides Nashe watershed in to 15 sub basins during stream network delineation and soil erosion prone in the basin (figure 6). 
Table 3. The severity of soil erosion corresponding to area in Nashe watershed.

\begin{tabular}{llll}
\hline Soil erosion condition & Sediment yield(ton/ha/yr) & Percent of area coverage (\%) & Watershed Area \\
\hline Low erosion & $0-25$ & 20 & $\mathrm{~N}-1,4 \& 14$ \\
Moderate erosion & $25-75$ & 60 & $\mathrm{~N}-2,3,5,6,7,9,12,13 \& 15$ \\
Severe erosion & $75-150$ & 20 & $\mathrm{~N}-8,10 \& 11$ \\
Extreme erosion & Above150 & 0 & none \\
\hline
\end{tabular}

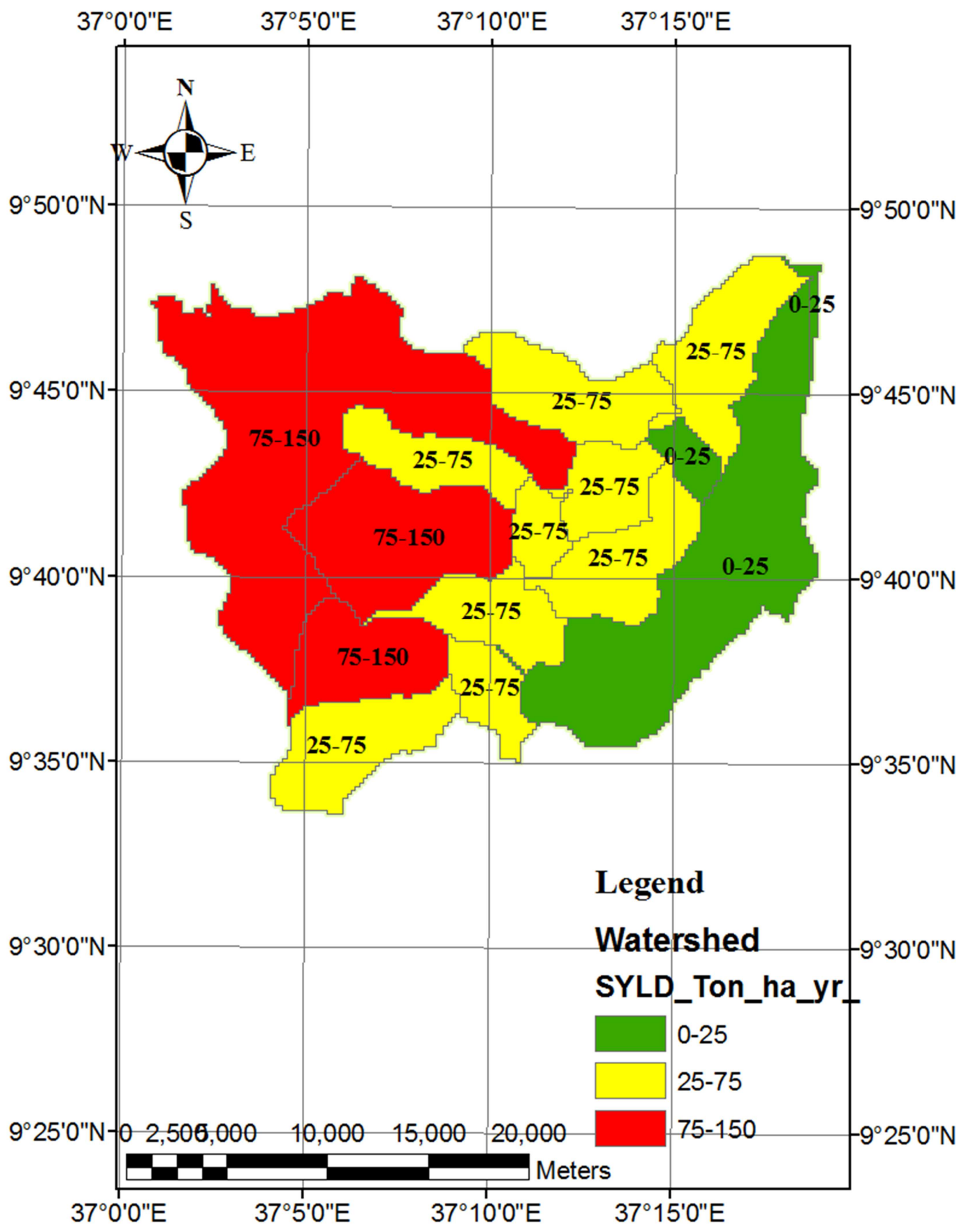

Figure 6. Spatial based distribution of sediment yield in Nashe watershed.

The temporal distributions of soil erosion have been estimated entire Nashe watershed based on the SWAT simulated average monthly sediment yields. According to the results, average sediment yields generated during July and August almost double average sediment yields of June \& September. The temporal distribution sediment yields of the study area has been divided in to four soil loss classes namely (January, February, March, April, November and December) monthly Low erosion time, (May) Monthly Moderate Erosion time, (June \& September) Monthly Severe soil erosion time and (July \& Aug) Monthly Extreme Soil erosion time (Table 4). 
Table 4. Temporal based distribution of sediment yield in Nashe watershed.

\begin{tabular}{|c|c|c|c|c|c|c|c|c|c|c|c|c|}
\hline Month & Jan. & Feb & Mar & Apr & May & Jun & July & Aug & Sep & Oct & Nov & Dec \\
\hline Sediment Yield (M ton) & 0.001 & 0.01 & 0.024 & 0.011 & 0.063 & 0.140 & 0.314 & 0.301 & 0.150 & 0.059 & 0.017 & 0.007 \\
\hline Total & 1.0878 & ons & & & & & & & & & & \\
\hline
\end{tabular}

\section{Conclusions}

The present study was performed to predict the spatial and temporal distribution of soil erosion using SWAT model in Nashe watershed Ethiopia. Consideration was done on spatial soil erosion prone area variation caused depending on land use change and slope difference major component for the generation of soil erosion. Sediment yield from each sub watershed were also determined and prone soil erosion area has been identified. This shows that physically based spatial distributed SWAT model was successfully used to simulate soil erosion modeling process of the catchments.

Stream flow has been calibrated and validated for watershed and reasonably good with coefficient of determination $\left(\mathrm{R}^{2}\right)$ values of 0.79 and 0.75 and NashSutcliffe values of 0.75 and 0.65 for calibration and validation respectively. SWAT model performance was adequately to simulate stream flows from Nashe sub basin and successfully result were obtained.

\section{References}

[1] Arnold, J. G., Srinivasn, R., Mettiah R. S., Williams J. R. (1998). Large area hydrologic modeling and assessement part one: Model Development. J. American Water Resources Association, Vol.34(1): 73-89.

[2] Awulachew, S. B. Mc Cartney, M., Steenhuis, T. S, Ahmed, A. A.2008 A review of hydrology, sediment and water resource use in the Blue Nile Basin. Colombo, Sri Lanka: International Water Management Institute (IWMI) 81p.

[3] Ayana Abdi Boru, Desalegn Chemeda Edosa and Ekasit Kositsakulchai, (2012). Simulation of Sediment Yield Using SWAT in Finchaa Watershed, EthiopiaKasetsart J. (Nat. Sci.), - pp. 46: 283-297.

[4] Betrie, G. D., Mohamed Y. A., Van Griensven A., and Srinivasan (2011). Sediment managment modeling in the Blue Nile Using SWAT Model. Hydrology and Earth System Science, 15, 807-818.

[5] Bezuayehu T. O. and Sterk G. (2008) Environmental impact of hydropower dam in Fincha'a watershed, Ethiopia Land use changes, erosion problems, and soil andwater conservation adoption.
[6] De Jong, S. M., Paracchini, M. L., Bertolo, F., Folving, S., Megier, J. and De Roo (1999) Regional assessment of soil erosion using the distributed model SEMMED and remotely sensed data: Catena, 37 (3-4): 291-308.

[7] Hurni H (1989) Soil for the Future. Environmental Research for Development Cooperation:Uni Press 62, University of Berne; Berne; 42-46.

[8] Ndorimana L., Saad, S. A., Eldaw, A. K., Naggar, O. M., Nindamutsa, A., Chan (2005). Watershed Erosion and Sediment Transport.

[9] Setegn, Srinivasan R., Dargahi B. and Melesse A. (2009). Spatial delineation of soil erosion vulnerability in Lake Tana basin, Ethiopia. The Royal Institute of technology, Stockholm, Sweden.

[10] Shimelis G. and Setegn (2009). Spatial Delineation of Soil Erosion Vulnerablity in the Lake Tana basin, Ethiopia. Hydrologic process. USA: Spatial Science Labolatory, Texas A \& M University, College Station, TX.

[11] Tamene, L., Park S. J., Dikau R. and Vlek P. L. G., (2006). Analysis of factors determining sediment yield variability in the highlands of northern Ethiopia:Geomorphology, 76 - 91.

[12] Teteri Bewket (2009). Assessment of soil erosion hazard and prioritization for treatment at the watershed level: Case study in the Chemoga Land Degradation, 609-622.

[13] USDA(1972). National engineering handbook: hydrology section 4.

[14] White, Smith D. and Wischmeier W. H (2008) Adapting the Soil and Water Assessement Tool (SWAT) for The Nile basin.

[15] Wischmeier W. \& Smith D. (1965). Predicting Rainfall Erosion Losses from Cropland East of the Rocky Mountains:Guide for Selection of Practices for Soil and Water Conservation. U.S. Department of Agriculture handbook No. 537.

[16] Williams, J. R., H. D. and Barndit, 1977. Sediment yield prediction Based on Watershed Hydrology. Transactions of American society of Agricultural Engineers, Vol.20 (6). 11001104.

[17] Yang W., Kanae, S., Oki, T., Koike, T. and Musiake K. (2003). Global potential soil erosion with reference to land use and climate changes: Hydrological Processes, 17 (14), 2913-2928. 